\title{
Tradisi dan PersepsiTentang Sunat Perempuan di Desa Sukamaju Kabupaten Muaro Jambi
}

\author{
Neny Heryani ${ }^{1}$, Herinawati ${ }^{2}$, Diniyati $^{3}$ \\ ${ }^{1,2,3}$ Poltekkes Kemenkes Jambi \\ e-mail: herinawati_burhanuddin@yahoo.com
}

\begin{abstract}
Abstrak
Sunat perempuan yang dilakukan di Indonesia umumnya di dasari oleh adanya tradisi atau budaya masyarakat yang diwariskan secara turun temurun. Namun sunat perempuan pada daerah tertentu di Indonesia merupakan salah satu bentuk keharusan pada sebagian masyarakat muslim. Sunat pada perempuan diyakini sebagai salah ibadah yang wajib dijalankan meskipun tuntunan agama tentang sunat perempuan masih jadi perdebatan. Penelitian ini bertujuan untuk mengetahui tradisidan persepsitentang sunat perempuan di Desa Suka Maju Kecamatan Mestong Kabupaten Muaro Jambi. Metode yang digunakan mixed methods adalah metode yang difokuskan untuk mengkombinasikan dua pendekatan, yaitu kuantitatif dengan pendekatan cross sectional dan kualitatif dengan pendekatan wawancara mendalam. 70 responden untuk penelitian kunatitatif dan 30 informan untuk penelitian kualitatif terdiri dari tokoh agama, tokoh adat, tokoh masyarakat, dukun beranak, orang tua yang mempunyai anak perempuan umur $\leq 3$ tahun.Pengumpulan data dengan wawancara mendalam dan dianalisis menggunakan analisis kualitatif yang bersifat induktif.Hasil analisis didapatkan bahwa persepsi masyarakat terhadap sunat perempuan yang dilaksanakan di Desa Sukamaju Kecamatan Mestong Kabupaten Muaro Jambi didasarkan oleh budaya atau tradisi yang sudah ada sejak zaman nenek moyang secara turun temurun. Akan tetapi jika dipandang dari segi agama sunat perempuan tidak tercantum didalam Al Qur'an maupun Al Hadits.Diharapkan Dinas Kesehatan Kabupaten Muaro Jambi dan tenaga kesehatan agar lebih menjalin kerjasama dengan sektor terkait dalam memberikan penyuluhan dan mengembangkan komunikasi, informasi dan edukasi kepada masyarakat guna keberhasilan kebijakan pemerintah dan perlindungan hak asasi dan hak reproduksi perempuan.
\end{abstract}

Kata Kunci : Persepsi, Tradisi, Sunat Perempuan.

(C) 2020- Neni Heryani, Herinawati, Diniyati Under the license CC BY-SA 4.0

\section{PENDAHULUAN}

Secara global paling tidak 100 juta lebih anak-anak perempuan mengalami risiko sunat perempuan pada setiap tahunnya atau hampir 6000 anak setiap harinya (Toubia, 1995:224). Sunat perempuan yang dilakukan di Indonesia umumnya di dasari oleh adanya tradisi atau budaya masyarakat yang diwariskan secara turun temurun. Namum sunat perempuan pada daerah tertentu di Indonesia merupakan salah satu bentuk keharusan pada sebagian masyarakat muslim. Sunat pada perempuan diyakini sebagai salah satu bentuk ibadah yang wajib dijalankan meskipun tuntunan agama tentang sunat perempuan masih jadi perdebatan (Musyarofah, 2003:3).

Sunat perempuan menimbulkan suatu trauma yang akan selalu ada dalam kehidupan dan pikiran seorang wanita yang mengalaminya, serta muncul sebagai kilas balik yang sangat mengganggu. Komplikasi psikologi dapat terpendam pada alam bawah sadar anak yang bisa menimbulkan gangguan perilaku, hilangnya kepercayaan dan rasa percaya 
diri sebagai efek serius yang dapat terjadi.Ketidakberdayaan perempuan yang sudah mulai dikontrol sejak kecil dengan cara disunat sebenarnya merupakan akibat konstruksi sosial yang selama ini menempatkan perempuan dalam kedudukan yang tidak penting dan memberi nilai yang kurang berarti terhadap apa yang dikerjakan tubuhnya (Musyarofah, 2013:6).

Di Provinsi Jambi khususnya di Desa Sukamaju Kecamatan Jambi Luar Kota pola kehidupan masyarakat secara umum sangat sederhana dan cenderung religius karena sebagian besar warga memeluk agama Islam. Mereka masih menjunjung tinggi hukum adat, budaya, dan tradisi yang berlaku dalam masyarakat meskipun dalam pelaksanaannya telah mengalami penyederhanaan.

Berdasarkan pengalaman waktu praktik di Desa Suka Maju Kecamatan Mestong Kabupaten Muaro Jambi pada Tahun 2017 di dapatkan bahwa sunat perempuan masih dilakukan bahkan sebagian besar perempuan-perempuan di lingkungan tersebut telah mengalami sunat, begitupun dengan keturunannya juga dilakukan sunat. Hal ini didorong dengan adanya tradisi dan juga anggapan masyarakat bahwa seorang perempuan yang disunat akan menjadi suci dan sah untuk menjalankan ibadah. Berdasarkan uraian latar belakang diatas maka tujuan dari penelitan ini adalah untuk mengetahui persepsi orang tua, tokoh agama, tokoh masyarakat, dan tokoh adat tentang sunat perempuan di Desa Suka Maju Kecamatan Mestong Kabupaten Muaro JambiTahun 2018.

\section{METODE}

Metode yang digunakan dalam penelitian ini adalah mixed methods. pendekatan kuantitatif digunakan rancangancross sectional dan kualitatif dengan pendekatan wawancara mendalam.Pada penelitian kualitatif dilakukan wawancara mendalam dengan tiga belas responden yang ditentukan secara pusposive. Wawancara semi terstruktur dilakukan untuk memperkuat data yang diperoleh dari kuesioner yang sebelumnya sudah diisi oleh responden 30 orang.Variabel penelitian Kuantitatifterdiri dari variabel bebas ( tradisi dan persepsi) dan Variabel terikatnya (sunat perempuan) serta variabel perancu (usia, pendidikan, status perkawinan, pekerjaan, dan sunat perempuan).Sampel pada penelitian ini adalah seluruh ibu yang mempunyai bayi 1 bulan sampai 3 tahun di Desa Suka Maju Kecamatan Mestong Kabupaten Muaro Jambi. Kriteria Inklusi pada penelitan ini yakni, Ibu yang mempunyai anak usia $\leq 3$ tahun, Bersedia ikut penelitian, Bertempat tinggal di Desa Suka Maju Kecamatan Mestong Kabupaten Muaro Jambi. Sedangkan kriteria Eksklusi yakni Pada saat penelitian tidak dapat diwawancarai.

\section{HASIL DAN PEMBAHASAN}

3.1. Hasil Penelitian Kuantitatif

Penelitian Mixed Method dilaksanakan dari bulan Mei sampai Desember 2018di Desa Sukamaju Kecamatan Mestong Kabupaten Muaro Jambi. Responden yang diambil dalam penelitian ini adalah dari Desa Sukamaju Kecamatan Mestong Kabupaten Muaro Jambi yang terdiri dari empat dusun. Responden dalam penelitian kuantitatif ini berjumlah 70 responden.

\subsubsection{Karakteristik Responden}

Berdasarkan hasil analisis data dengan mengubungkan karekteristik responden yakniusia, pendidikan, pendapatan, perkawinan, dan pekerjaanmemperlihatkan 
bahwa pada tabel 1 karakteristik responden

tidak terlihat ada perbedaan bermakna

Tabel 1.KarakteristikResponden menurut Usia,

Pendidikan, Status Perkawinan, dan Pekerjaan

\begin{tabular}{|c|c|c|c|}
\hline \multirow{2}{*}{ Karakteristik } & \multicolumn{2}{|c|}{ Responden } & \multirow{2}{*}{ Nilai $p$} \\
\hline & $n=70$ & $\%$ & \\
\hline \multicolumn{4}{|l|}{ Usia (tahun) } \\
\hline $20-30$ & 53 & 75,7 & 0,751 \\
\hline $31-40$ & 17 & 24,3 & \\
\hline \multicolumn{4}{|l|}{ Pendidikan } \\
\hline Tidak tamat SD & 6 & 8,6 & \\
\hline SD & 6 & 8,6 & 0,418 \\
\hline SMP & 41 & 58,6 & \\
\hline SMU & 12 & 17,1 & \\
\hline Diploma & 4 & 5,7 & \\
\hline PT & 1 & 1,4 & \\
\hline \multicolumn{4}{|c|}{ Status perkawinan } \\
\hline Menikah & 68 & 96 & 0,312 \\
\hline Cerai & 2 & 4 & \\
\hline \multicolumn{4}{|l|}{ Pekerjaan } \\
\hline IRT & 2 & 2,9 & 0,206 \\
\hline Petani & 55 & 78,6 & \\
\hline PNS & 1 & 1,4 & \\
\hline \multicolumn{4}{|c|}{$\begin{array}{l}\text { Swasta } \\
\text { Tabel 2. Pistribusi responden berdasarkap,3kuesioner Persepsi tentang sunat }\end{array}$} \\
\hline
\end{tabular}

\begin{tabular}{|c|c|c|c|c|c|}
\hline \multirow{3}{*}{ No } & \multirow{3}{*}{ Pernyataan } & \multicolumn{4}{|c|}{ Persepsi } \\
\hline & & \multicolumn{2}{|c|}{ Setuju } & \multicolumn{2}{|c|}{$\begin{array}{l}\text { Tidak } \\
\text { setuju }\end{array}$} \\
\hline & & $\mathbf{f}$ & $\%$ & $\mathbf{f}$ & $\%$ \\
\hline 1 & $\begin{array}{l}\text { Saya merasa kasihan ketika mengetahui masih ada perempuan yang } \\
\text { di khitan }\end{array}$ & 16 & 22.9 & 54 & 77.1 \\
\hline 2 & Saya mendukung pelarangan praktik khitan perempuan & 14 & 20 & 56 & 80 \\
\hline 3 & $\begin{array}{l}\text { Khitan perempuan diperbolehkan asalkan dilakukan oleh tenaga } \\
\text { medis }\end{array}$ & 56 & 80 & 14 & 20 \\
\hline 4 & $\begin{array}{l}\text { Saya merasa telah melanggar ajaran agama apabila tidak melakukan } \\
\text { khitan perempuan }\end{array}$ & 43 & 61.4 & 27 & 38.6 \\
\hline 5 & $\begin{array}{l}\text { Saya merasa senang dengan adanya peraturan pemerintah yang } \\
\text { melarang praktik khitan perempuan. }\end{array}$ & 15 & 21.4 & 55 & 78.6 \\
\hline 6 & $\begin{array}{l}\text { Saya akan mencegah perempuan yang ingin melakukan khitan } \\
\text { perempuan. }\end{array}$ & 10 & 14.3 & 60 & 85.7 \\
\hline 7 & $\begin{array}{l}\text { Khitan perempuan merupakan salah satu bentuk kekerasan terhadap } \\
\text { perempuan. }\end{array}$ & 6 & 8.6 & 64 & 91.4 \\
\hline 8 & $\begin{array}{l}\text { Saya merasa lega apabila berhasil mencegah seorang perempuan } \\
\text { yang akan melakukan khitan perempuan }\end{array}$ & 10 & 14.3 & 60 & 85.7 \\
\hline 9 & Saya tidak akan mengkhitankan anak perempuan saya. & 12 & 17.1 & 58 & 82.9 \\
\hline 10 & Saya berpendapat bahwa khitan perempuan melanggar HAM. & 10 & 14.3 & 60 & 85.7 \\
\hline 11 & $\begin{array}{l}\text { Saya merasa senang apabila jumlah perempuan yang dikhitan } \\
\text { menurun. }\end{array}$ & 12 & 17.1 & 58 & 82.9 \\
\hline 12 & $\begin{array}{l}\text { Saya tidak melakukan khitan, meski orang lingkungan sekitar saya } \\
\text { melakukannya. }\end{array}$ & 10 & 14.3 & 60 & 85.7 \\
\hline 13 & $\begin{array}{l}\text { Pemerintah Indonesia seharusnya mengeluarkan peraturan yang } \\
\text { menegaskan pelarangan khitan perempuan. }\end{array}$ & 12 & 17.1 & 58 & 82.9 \\
\hline 14 & Khitan perempuan tidak memiliki manfaat medis yang jelas. & 17 & 24.3 & 53 & 75.7 \\
\hline 15 & $\begin{array}{l}\text { Tenaga medis yang melakukan khitan pe }{ }^{3} \text { rempuan perlu ditindak } \\
\text { secara hukum karena melakukan kekerasan terhadap perempuan. }\end{array}$ & 7 & 10 & 63 & 90 \\
\hline
\end{tabular}


usia, pendidikan, pendapatan, perkawinan, dan pekerjaan $(\mathrm{p}>0,005)$.

Berdasarkan tabel 2dketahui bahwa persepsi khitan perempuan diperbolehkan asalkan dilakukan oleh tenaga medis yang setuju 56 responden (80\%), khitan perempuan merupakan salah satu bentuk kekerasan terhadap perempuan yang tidak setuju 64 responden $(91,4 \%)$.
3.2.1Sunat Perempuan Berdasarkan Perspektif Agama

Pandangan agama terhadap sunat perempuan

Empat tokoh agama di Sukamaju mengemukakan pandangan agama terhadap sunat perempuan terdiri dari empat pendapat. Satu dari empat tokoh agama mengemukakan bahwa sunat perempuan itu istilahnya khifadh yaitu mengambil bizhir-bizhir perempuan yang harus dipotong disaat berkhifadh.

Tabel 4.3 Distribusi responden berdasarkan kuesioner Tradisitentang sunat perempuan di Desa Sukamaju Kec. Mestong Kabupaten Muaro Jambi

\begin{tabular}{|c|l|c|c|c|c|}
\hline \multirow{2}{*}{ No } & \multicolumn{1}{|c|}{ Pernyataan } & \multicolumn{3}{|c|}{ Persepsi } \\
\cline { 2 - 5 } & \multicolumn{1}{|c|}{ Setuju } & \multicolumn{1}{c|}{ Tidak setuju } \\
\cline { 2 - 5 } & \multicolumn{1}{|c|}{$\begin{array}{c}\text { f } \\
\text { Saya akan mendorong anggota perempuan untuk melakukan khitan } \\
\text { perempuan }\end{array}$} & 50 & 71.4 & 20 & 28.6 \\
\hline 2 & $\begin{array}{l}\text { Saya berpendapat khitan perempuan memiliki pengaruh negatif } \\
\text { terhadap kondisi fisik perempuan }\end{array}$ & 14 & 20 & 56 & 80 \\
\hline 3 & $\begin{array}{l}\text { Saya merasa telah melanggar ajaran agama apabila tidak melakukan } \\
\text { khitan perempuan }\end{array}$ & 43 & 61.4 & 27 & 38.6 \\
\hline 4 & $\begin{array}{l}\text { Saya tetap melakukan khitan perempuan karena tuntutan agama dan } \\
\text { tradisi. }\end{array}$ & 50 & 71.4 & 20 & 28.6 \\
\hline 5 & $\begin{array}{l}\text { Khitan perempuan dapat mengurangi kenikmatan pada saat } \\
\text { berhubungan seksual. }\end{array}$ & 8 & 11.4 & 62 & 88.6 \\
\hline 6 & $\begin{array}{l}\text { Saya merasa kesal apabila ada orang yang melakukan khitan } \\
\text { perempuan hanya karena mengikuti ajaran agama dan tradisi }\end{array}$ & 17 & 24.3 & 53 & 75.7 \\
\hline 7 & Khitan juga wajib dilakukan terhadap perempuan & 38 & 54.3 & 32 & 45.7 \\
\hline 8 & Saya takut akan konsekuensi yang ditimbulkan dari khitan perempuan. & 16 & 22.9 & 54 & 77.1 \\
\hline
\end{tabular}

Sumber : Data Primer

Berdasarkan tabel di atas, diperolah gambaran tentang tradisi adalah saya akan mendorong anggota perempuan untuk melakukan khitan perempuan, saya tetap melakukan khitan perempuan karena tuntutan agama dan tradisi yang setuju 50 responden (71,4\%), khitan perempuan akan mengurangi kenikmatan pada saat berhubungan seksual tidak setuju 62 responden $(88,6 \%)$

\subsection{Hasil Penelitian Kualitatif}

Ada seorang tokoh agama mengemukakan bahwa sunat perempuan itu merupakan budaya, adat istiadat secara turun-temurun. Selanjutnya dua dari empat tokoh agama mengemukakan bahwa sunat perempuan merupakan suatu kemuliaan bagi kaum perempuan dengan tujuan untuk menghilangkan rangsangan bagi kaum perempuan tetapi dalam pelaksanaannya tidak berlebihan. 
Menurut Arivia (1996) dikutip oleh Sumarni (2015:5-6) bahwa segala bentuk pemotongan bagian kelamin seperti penyunatan adalah kepercayaan ritual yang bermula dari agama primitif yang tidak ada hubungannya dengan alasan medis, kesehatan atau ilmu pengetahuan. Sunat perempuan di Indonesia diyakini sebagai salah satu bentuk ibadah atau perintah agama sehingga tidak mudah untuk dihapuskan dan bisa menimbulkan folemik di masyarakat. Praktik sunat perempuan sudah lama berlangsung dan dilaksanakan secara turun- temurun. Diperkirakan bahwa sunat perempuan bersumber dari ajaran agama Islam yang kemudian berkembang menjadi tradisi masyarakat setempat. Namun secara keseluruhan tidak ada keterangan yang dapat menjelaskan khitan perempuan merupakan ajaran agama islam atau merupakan tradisi kuno yang diwariskan turun-temurun dengan alasan agama.

Dua dari empat tokoh agama mengemukakan bahwa hukum dari sunat perempuan adalah sunah, sedangkan dua orang tokoh agama lainnya mengemukakan bahwa hukum dari pada sunat perempuan itu adalah wajib tetapi dalam pelaksanaannya tidak berlebihan dikarenakan sebagian masyarakat Desa Sukamaju mengikuti ajaran Imam Syafi'i.

Maidul Autar al Imam al Asyaukan (1973) dikutip oleh Sumarni,dkk (25:6-7) menyatakan bahwa hukum sunat pada perempuan adalah makrumatun atau suatu kemuliaan yang baik dilakukan dengan tujuan untuk menghilangkan najis dan menjadikannya sebagai perempuan yang suci. Namun sebagian ulama berpendapat bahwa tidak ada hadist yang soheh yang berisi anjuran untuk melakukan sunat perempuan.
Dua dari empat tokoh agama mengemukakan apabila seorang perempuan tidak di sunat ditinjau dari ajaran agama islam hanya sebatas sunah namun dikuatirkan akan berbuat sesuatu yang tidak di inginkan karena mempunyai nafsu yang agak lebih dari pada nafsu perempuan yang di sunat. Sedangkan dua tokoh agama lainnya menyatakan bahwa perempuan itu harus disunat tetapi dalam pelaksanaannya tidak berlebihan.

Menurut pendapat Al-Mawardi dan hadist yang diriwayatkan oleh Abu Daud sunat pada perempuan memang disunahkan dalam Islam. Banyak kaum muslim menginterprestasikan sunat perempuan sebagai kewajiban yang diharuskan oleh kitab suci Al-Qur'an. Para ahli fiqih sepakat dengan pendapat ulama bahwa sunat perempuan harus dilaksanakan tanpa berlebihan dengan tujuan utama adalah untuk menstabilkan syahwat, sebaliknya jika sunat dilaksanakan secara berlebihan akan mengakibatkan lemah syahwat (Sumarni,dkk:2005:7).

Tiga dari empat tokoh agama mengemukakan bahwa ajaran tentang sunat perempuan tidak tercantum dalam Al-Qur'an atau Hadist. Satu tokoh agama mengemukakan bahwa ajaran tentang sunat perempuan tercantum didalam AlQur'an.

Tiga dari empat tokoh agama mengemukakan bahwa jika seorang perempuan tidak disunat dalam melaksanakan ibadah tetap sah dalam melaksanakan ibadah. Satu tokoh agama mengemukakan bahwa apabila seorang perempuan tidak disunat dapat menyalahi sunah rasul.

Menurut mazhab Syafi'i khitan perempuan merupakan suatu keharusan (kewajiban) yang diturunkan oleh ajaran 
agama Islam dengan tujuan untuk menjaga kesucian (kebersihan). Apabila kewajiban tersebut tidak dijalankan dianggap haram hukumnya sehingga ibadahnya atau sholatnya tidak sah. Dasar hukum yang dipakai adalah sebuah hadist yang diriwayatkan oleh Ahmad, Muslim dan Tarmidzi. Namun sebagian ulama mengatakan bahwa tidak ada hadist yang soheh untuk dijadikan pedoman hukum bahwa seorang perempuan harus di sunat.

Dua dari empat tokoh agama menyatakan bahwa pemerintah harus memberikan sosoalisasi kepada masyarakat tentang manfaat dari kebijakan pemerintah tersebut sehingga tidak terjadi kebimbangan dimasyarakat. Dua tokoh agama menyatakan bahwa pemerintah tidak boleh secara tegas melarang untuk tidak melakukan sunat perempuan karena akan terbentur kepada masyarakat yang berpedoman kepada ajaran Imam Syafi'i.

Dalam rangka penghapusan segala bentuk diskriminasi terhadap perempuan (CEDAW) melalui UU No.7 Tahun 1984 pada konferensi perempuan ke IV di Beijing 1985, di pertegas kembali tentang masalah perusakan alat kelamin perempuan. Indonesia konsisten didalam mendukung terlindunginya hak perempuan terhadap segala bentuk diskriminasi termasuk kekerasan. Sunat terhadap anak perempuan terutama yang merusak organ reproduksi merupakan suatu tindakan kekerasan terhadap perempuan.

Menteri Negara Pemberdayaan Perempuan mendukung semua usaha untuk menghapus pelaksanaan sunat perempuan dengan menerbitkan larangan bagi petugas medis/para medis, termasuk fasilitas kesehatan pemerintah maupun swasta, untuk tidak melakukan medikalisasi sunat pada perempuan karena tidak pernah ada ada dalam standar pelayanan kesehatan.

\subsubsection{Sunat Perempuan Berdasarkan} Perspektif Budaya

Menurut tokoh adat sunat perempuan merupakan adat dari ajaran agama Islam yang harus dilaksanakan oleh seorang perempuan. Agama tidak bisa dilepaskan dari budaya, agama tumbuh dan berkembang seiring dengan budaya. Sunat atau khitan merupakan budaya yang pernah digunakan sebagai simbol perjanjian dengan umatnya, sehingga tradisi khitan bukanlah tradisi asli dari ajaran agama Islam karena dalam tradisi Islam aturan-aturan mengenai khitan tidak dijumpai dalam Alqur'an maupun Hadist.

Seluruh tokoh adat mengemukakan bahwa pelaksanaan sunat perempuan dilakukan oleh dukun beranak dimana dalam pelaksanaannya membawa perlengkapan persyaratan secara lengkap seperti : beras, cabe, bumbu dapur secukupnya. Dari hasil wawancara terhadap dukun beranak pada umumnya para dukun dalam pelaksanaannya menggunakan alat pemotong,berupa silet atau pisau lipat dan alat tersebut belum memenuhi standar kesehatan.

Hal tersebut dapat menimbulkan risiko terjadinya iritasi dan infeksi pada daerah sekitar vagina. Khitan perempuan diyakini oleh masyarakat merupakan suatu ritual yang syarat dengan nilai-nilai keagamaan dan merupakan proses penting dari kehidupan seorang anak perempuan.

Dua tokoh adat mengemukakan bahwa apabila seorang anak perempuan tidak disunat akan mendapatkan kesulitan pada waktu proses persalinan. Satu tokoh adat mengemukakan bahwa apabila seorang anak perempuan tidak disunat belum masuk dalam ajaran agama Islam. 
Makna sebagai seorang perempuan di masyarakat tidak terlepas dari mitosmitos seksualitas yang berkembang, yaitu tentang perilaku seksual dan bagaimana perasaan seseorang terhadap tubuhnya sendiri Burns, dkk(1997). Mitos-mitos ini mempunyai efek yang merugikan peran gender, menjadikan perempuan tidak memiliki kontrol terhadap kehidupan seksualnya.

Menurut Dawala (1999) dikutip oleh Sumarni, dkk (2015:14) sunat perempuan merupakan kekerasan seksual dan kekerasan sosial yang harus ditanggung perempuan demi nilai-nilai perkawinan dan identifikasi sosial. Sunat juga dikuatkan oleh budaya setempat, yang menempatkan tubuh perempuan sebagai simbol identitas moralitas budaya yang harus dipelihara.

Salah satu tokoh adat mengemukakan bila sudah ada program dari pemerintah yang tidak memperbolehkan lagi pelaksanaan sunat pada perempuan akan mengikuti program pemerintah tersebut. Dua tokoh adat mengemukakan bahwa pelaksanaan sunat perempuan tergantung kepada orang tuanya masing-masing.

Dalam menanggulangi masalah sunat perempuan pemerintah telah melarang adanya praktik sunat perempuan bagi medis/para medis, termasuk fasilitas kesehatan pemerintah maupun swasta untuk tidak melakukan medikalisasi sunat pada perempuan dengan alasan tidak ada dalam standar pelayanan kesehatan.

Dua tokoh adat mengemukakan bahwa tidak ada pengaruh sunat terhadap perilaku perempuan. satu tokoh adat mengemukakan apabila seorang anak perempuan disunat akan menjadi penurut. Tidak ada perbedaan antara perempuan yang dikhitan dengan yang tidak dikhitan dalam berperilaku.

Sikap yang terbentuk melalui proses internalisasi merupakan sikap yang cendrung akan di pertahankan oleh individu dan biasanya tidak mudah berubah selama sistem nilai yang ada dalam diri individu yang bersangkutan masih bertahan menurut Azwar (1995) dikutip oleh Musyarofah, dkk (2003:5455).

Dalam kontruksi budaya suatu masyarakat terdapat nilai-nilai dan normanorma yang melandasi sikap dan perilaku masing-masing anggotanya. Perilaku khitan perempuan yang dilakukan oleh masyarakat didasari oleh adanya proses sosialisasi yang berlangsung cukup efektip melalui institusi keluarga, pergaulan hidup sehari-hari antar anggota masyarakat serta pengaruh institusi adat dan agama.

323 Persepsi Tokoh Masyarakat di Desa Skamaju Kecamatan Jambi luar kota Kabupaten Muaro Jambi

Dua dari lima tokoh masyarakat mengemukakan bahwa sunat perempuan merupakan adat istiadat atau tradisi yang diwariskan secara turun temurun. Dua tokoh masyarakat mengemukakan bahwa tujuan sunat perempuan adalah untuk mendidik anak menjaga kebersihan kemaluannya. Satu tokoh masyarakat lainnya mengemukakan bahwa sunat perempuan hukumnya sunah.

Sunat atau khitan merupakan budaya yang pernah digunakan sebagai simbol perjanjian dengan umatnya, sehingga tradisi khitan bukanlah tradisi asli dari ajaran agama Islam karena dalam tradisi Islam aturan-aturan mengenai khitan tidak dijumpai dalam Al-Qur'an maupun hadist.

Dua dari lima tokoh masyarakat mengemukakan bahwa hendaknya 
pemerintah memberikan himbauan dan sosialisasi antara pihak medis dan agama kepada masyarakat tentang tidak diperbolehkan lagi pelaksanaan sunat perempuan. Satu tokoh masyarakat mengemukakan bahwa kebijakan pemerintah yang tidak memperbolehkan lagi pelaksanaan sunat perempuan sedikit bertentangan dengan syariat agama Islam. Sedangkan satu tokoh masyarakat lainnya mengemukakan bahwa pelaksanaan sunat perempuan tidak mengganggu perkembangan tubuh anak perempuan.

Tindakan penggoresan dan pemotongan sebagian kecil klitoris pada sunat perempuan adalah merupakan pelanggaran hak asasi manusia. Undangundang No. 39/1999 tentang HAM, menyatakan hak anak adalah hak asasi manusia (pasal 52 ayat 1), seseorang anak berhak mendapatkan perlindungan dari segala bentuk kekerasan baik fisik maupun mental (pasal 58 ayat 1).

Tiga tokoh masyarakat mengemukakan bahwa cara menyikapi masyarakat agar tidak lagi melaksanakan sunat perempuan adalah dengan cara memberikan penyuluhan, himbauan, membuat logo tentang keuntungan dan kerugian sunat perempuan. Satu tokoh masyarakat mengemukakan bahwa apabila anak perempuan tidak di sunat tidak apaapa karena dalam pelaksanaannya tidak mengganggu pertumbuhan dan perkembangan anak perempuan. Satu tokoh masyarakat lainnya mengemukakan bahwa para orang tua anak perempuan masih suka melaksanakan sunat terhadap anak perempuan.

Tiga orang tokoh masyarakat mengemukakan bahwa alasan masyarakat masih melaksanakan sunat perempuan adalah dikarenakan sunat perempuan merupakan adat yang di turunkan oleh nenek moyang. Satu tokoh masyarakat mengemukakan bahwa alasan masyarakat masih melaksanakan sunat perempuan karena tidak ada penyuluhan dari Dinas Kesehatan tentang sunat perempuan. Satu tokoh masyarakat mengemukakan alasan masih melaksanakan sunat perempuan adalah apabila perempuan tidak di sunat nantinya akan mempersulit pada waktu proses persalinan.

Khitan perempuan yang dilakukan di Indonesia umumnya didasari oleh adanya tradisi (budaya) masyarakat yang diwariskan secara turun-temurun. Menurut Durkheim (1984) dikutip oleh (Musyarofah, 2003:3) budaya adalah sesuatu yang berada di luar kemauan individu, di luar kemampuan perorangan dan memaksakan kehendaknya pada setiap individu. Adanya tekanan-tekanan sosial sering menghalangi individu untuk melakukan hal-hal yang tidak diinginkan.

3.4. Pendapat Dukun Beranak di Desa Sukamaju Kecamatan Jambi luar kota Kabupaten Muaro Jambi

Dua orang dukun beranak mengemukakan bahwa seorang anak perempuan itu memang harus di sunat agar bersih. Satu orang dukun beranak mengemukakan bahwa sunat perempuan adalah mengikis klentit daripada seorang anak perempuan.

Khitan perempuan yang dilakukan oleh para dukun beranak di desa Mekar Jaya merupakan tindakan yang membahayakan karena mengandung risiko terjadinya infeksi, perdarahan dan iritasi di sekitar vagina. Dari sisi dampak khususnya yang menyangkut seksual, walaupun hanya sedikit bagian klitoris yang dipotong maka akan terjadi kepekaan pada daerah klitoris berkurang sebab klitoris merupakan organ kecil yang sangat sensitif, oleh karena itu di dalam melakukan hubungan seksual 
akan mengalami gangguan pada pencapaian orgasme (Musyarofah, 2003:21-24).

Menurut Toubia (1995) dikutip

oleh Ida (2005:20) alasan-alasan masyarakat melakukan sunat perempuan adalah alasan kebersihan, alasan proteksi laki-laki atau alasan penerimaan, alasan kesehatan, alasan agama, alasan moral

Khitan diyakini sebagai salah satu bentuk ibadah yang wajib dijalankan meskipun tuntunan agama tentang khitan perempuan masih menjadi perdebatan. Penanaman nilai-nilai ketaatan menjalankan kewajiban telah dimulai sejak kecil, apabila tidak dilakukan diyakini akan ada efek negatif bagi kehidupan anak perempuan di masa yang akan datang.

Seluruh dukun beranak mengemukakan cara pelaksanaan sunat yang selama ini dilakukan yaitu dengan cara mengikis ujung klentit dengan silet atau pisau kecil kemudian dibersihkan dengan kapas.

Menurut Lax (2000) dikutip oleh Ida (2005:23-24) menyebutkan empat variasi FGM sebagai berikut: sunna yaitu memotong atau menghilangkan prepuce klitoris, modifikasi sunna meliputi pemotongan sebagian atau keseluruhan klitoris, klitoridektomi atau eksisi yaitu menghilangkan sebagian atau seluruh klitoris dan juga labia minora, kemudian infibulasi yaitu melakukan pemotongan klitoris, labia minora, labia mayora kemudian dijahit.

Peran dukun beranak dalam melakukan khitan pada anak perempuan tidak lepas dari adanya norma-norma masyarakat yang mendukung dilakukannya khitan. Adanya anggapan apabila seorang dukun beranak tidak melakukan khitan mempunyai nilai yang tidak baik oleh masyarakat setempat karena mengingkari hukum-hukum yang berlaku dalam adat tradisi masyarakat (Sumarni dkk, 2005:49$51)$.

Seluruh dukun beranak mengemukakan bahwa pelaksanaan sunat perempuan yang selama ini dijalankan tidak ada dampak terhadap anak perempuan.Menurut Toubia (1995) dikutip oleh Ida (2005:2) mengemukakan komplikasi FGM terdiri dari: rasa sakit yang berlebihan, infeksi saluran kencing, infeksi pelvic, berkurangnya kesuburan dan kemandulan, hemorrhage dan dysmenorrhea.

Praktik sunat perempuan mempunyai dampak baik fisik maupun psikologis namun dalam hal ini masyarakat tidak mengetahui dan memahami bahwa sunat perempuan merupakan ancaman bagi kesehatan reproduksi sekaligus sebagai bentuk kekerasan terhadap anak perempuan dan pelanggaran hak-hak asasi manusia menurut Dawala (1999) dikutip oleh Sumarni, dkk (2005:13). Indonesia dalam hal ini belum terlihat mendalami keberadaan sunat perempuan sebagai persoalan yang serius melanggar hak-hak asasi dan diskriminasi terhadap perempuan menurut Ida (2005:31).

3.2.4 Pendapat para orang tua anak perempuan umur $\leq 3$ tahun

Seluruh orang tua mengemukakan bahwa sunat perempuan adalah hukumnya wajib bagi orang Islam baik laki-laki maupun perempuan.

Khitan perempuan dimaknai sebagai suatu keharusan (kewajiban) yang diturunkan oleh ajaran agama Islam. Pandangan bahwa khitan adalah bagian dari ajaran agama Islam tampaknya merupakan fenomena di Indonesia. Khitan perempuan dijalankan dan dipertahankan dalam masyarakat karena alasan-alasan agama namun secara keseluruhan tidak ada 
keterangan pasti yang menjelaskan khitan perempuan merupakan ajaran agama Islam atau merupakan tradisi yang diwariskan secara turun-temurun dengan alasan agama.

Seluruh orang tua mengemukakan manfaat dari pelaksanaan sunat pada anak perempuan adalah agar dalam proses persalinan enak dan memang wajib harus dijalankan.Menurut Lax (2000) dikutip oleh Sumarni (2005:14) sunat pada perempuan merupakan hukum seks yang buruk, sebuah penjelmaan fisik yang tidak memungkinkan perempuan untuk menikmati seks.

Menurut Dawala (1999) dikutip oleh Sumarni (2005:14) sunat pada perempuan merupakan kekerasan seksual dan kekerasan sosial yang harus ditanggung perempuan demi nilai-nilai perkawinan dan identifikasi sosial.

Seluruh orang tua mengemukakan bahwa tidak ada dampak dalam pelaksanaan sunat perempuan. Menurut Lightfoot-Klein (1989) dikutip oleh Sumarni, dkk (2005:9) risiko yang terjadi setelah sunat dapat berupa: perdarahan yang banyak, tetanus, shock, infeksi traktus urinarius dan incontinentia urinae.

Seluruh orang tua tidak setuju tentang kebijakan pemerintah yang tidak memperbolehkannya lagi tindakan sunat perempuan dikarenakan alasan agama.

Sunat perempuan menimbulkan suatu trauma yang akan selalu ada dalam kehidupan dan pikiran seorang wanita yang mengalaminya. Komplikasi psikologi dapat terpendam pada alam bawah sadar anak yang bisa menimbulkan gangguan perilaku, hilangnya kepercayaan dan rasa percaya diri sebagai efek serius yang dapat terjadi, namun para orang tua tidak menyadarinya dikarenakan kurangnya penyuluhan tentang dampak pelaksanaan sunat perempuan.

Berdasarkan uraian diatas dapat disimpulkan bahwa sunat perempuan tidak boleh dilaksanakan karena melanggar hak asasi dan hak reproduksi perempuan. Dalam hal ini pemerintah juga telah mempertegas dengan cara mengeluarkan surat perintah tentang larangan sunat perempuan. Dalam operasionalnya diharapkan kepada dukun beranak tidak lagi melakukan praktik sunat perempuan serta mampu menyampaikan kepada masyarakat guna keberhasilan program pemerintah demi kesejahteraan perempuan.

\section{KESIMPULAN}

Bertitik tolak dari hasil penelitian dan uraian pembahasan dengan mengacu pada tujuan yang telah ditetapkan, maka dapat disimpulkan beberapa hal sebagai berikut:

1. Persepsi masyarakat tentang sunat perempuan di Desa Sukamaju menyatakan bahwa sunat perempuan masih dilaksanakan karena merupakan tradisi dan ada anggapan masyarakat bahwa perempuan yang tidak disunat sulit dalam proses persalinan sehingga mewajibkan perempuan harus disunat.

2. Persepsi tokoh agama terhadap sunat perempuan yakni sunah, tokoh agama tersebut pun menyatakan bahwa ketentuan sunat perempuan tidak tercantum didalam Alqur'an dan Al hadistsehingga hukum sunat perempuan tersebut masih belum ada petunjuk yang pasti. Pendapat dari dua tokoh agama lain menyatakan bahwa hukum dari sunat perempuan wajib.

3. Persepsi tokoh masyarakat tentang Sunat Perempuan di Desa Sukamaju Kecamatan Jambi luar kota Kabupaten 
Muaro Jambi menyatakan bahwa sunat perempuan merupakan adat istiadat yang sudah ada sejak zaman nenek moyang dan belum dapat di hilangkan secara keseluruhan dan mengatakan bahwa perlu disosialisasikan antara tim medis dan departemen agama tentang keuntungan dan kerugian dari sunat perempuan sehingga tidak terjadi kebimbngan di masyarakat.

4. Persepsi tokoh adat tentang sunat perempuan di Desa Sukamaju Kecamatan Jambi luar kota Kabupaten Muaro Jambi menyatakan bahwa sunat perempuan masih dilaksanakan karena merupakan adat istiadat sejak zaman nenek moyang mereka dan belum dapat dihilangkan secara keseluruhan. Menurut tokoh adat tersebut dalam pelaksanaannya dilakukan oleh dukun beranak dan membawa persyaratan adat istiadat setempat. Adapun tanggapan tokoh adat setempat tentang tidak diperbolehkannya lagi pelaksanaan sunat perempuan oleh pemerintah menyatakan akan mengikuti program pemerintah tentang

tidak diperbolehkannya lagi pelaksanaan sunat perempuan. Karena apabila perempuan tidak disunat tidak ada pengaruh terhadap perilaku perempuan tersebut.

\section{UCAPAN TERIMA KASIH}

Peneliti mengucapkan terima kasih kepada pihak-pihak yang telah berpartisipasi dalam penelitian ini.

\section{DAFTAR PUSTAKA}

1. Arikunto, Suharsimi, 2006Prosedur Penelitian Suatu Pendekatan Praktik. Penerbit Rineka Cipta. Jakarta: xi + 33 hlm.
2. Danim, Sudarwan, 2003Metode Penelitian Kebidanan : Prosedur, Kebijakan dan Etik. Jakarta: xii +333 hlm.

3. Ida, Rachmah, 2005Sunat, Belenggu Adat Perempuan Madura. Penerbit Ford Foundation. Yogyakarta: xvi + $114 \mathrm{hlm}$

4. Koblinnsky, Marge, et al, 2003Kesehatan wanita sebuah perspektif global. Jakarta.hlm

5. Modul YPKP, 2006Perempuan dan agama. Penerbit Ford Foundation. Jakarta: $\mathrm{x}+71 \mathrm{hlm}$.

6. Modul

YPKP,2006Kesehatan Reproduksi. Penerbit Ford Foundation. Jakarta: $\mathrm{x}$ $+133 \mathrm{hlm}$.

7. Musyarofah, Ristiani, et al, 2003Khitan Perempuan antara tradisi dan ajaran agama. Penerbit Ford Foundation. Yogyakarta: xiv + $106 \mathrm{hlm}$.

8. Notoatmodjo, Soekidjo, 2003Ilmu Kesehatan Masyarakat, Prinsipprinsip dasar. Penerbit Rineka Cipta. Jakarta: ix + 214 hlm.

9. Notoatmodjo, 2005Promosi Kesehatan teori dan aplikasi. Penerbit Rineka Cipta. Jakarta: viii + 389 hlm.

10. Sugiyono, 2008Metode Penelitian Kuantitatif Kualitatif dan $R$ \& D. Penerbit ALFA BETA. Bandung: $\mathrm{x}+$ $334 \mathrm{hlm}$.

11. Sumarni, et al, 2005. Sunat Perempuan di bawah bayang-bayang tradisi. Penerbit For Foundation. Jakarta: viii + 208 hlm. 